\title{
Limited Association Between Ascorbate Concentrations and Vitamin C Transporters in Renal Cell Carcinoma Cells and Clinical Samples
}

\author{
Christina Wohlrab ${ }^{a, b}$ Margreet C.M. Vissers ${ }^{c} \quad$ Eleanor R. Burgess ${ }^{a}$ \\ Maria Nonis $^{a} \quad$ Elisabeth Phillips $^{\mathrm{a}} \quad$ Bridget A. Robinson $^{\mathrm{a}, \mathrm{d}} \quad$ Gabi U. Dachs ${ }^{\mathrm{a}}$ \\ aMackenzie Cancer Research Group, Department of Pathology and Biomedical Science, University of \\ Otago, Christchurch, New Zealand, 'Fianostics GmbH, Technologie- und Forschungszentrum, Wiener \\ Neustadt, Austria, 'Centre for Free Radical Research, Department of Pathology and Biomedical Science, \\ University of Otago, Christchurch, New Zealand, 'Canterbury Regional Cancer and Hematology Service, \\ Canterbury District Health Board, Christchurch, New Zealand
}

\author{
Key Words \\ Vitamin $\mathrm{C} \cdot \mathrm{ccRCC} \cdot \mathrm{pRCC} \cdot \mathrm{SVCT} 1 \cdot \mathrm{SVCT} 2$
}

\begin{abstract}
Background/Aims: Maintenance of whole-body ascorbate levels and distribution is mediated via sodium-dependent vitamin C transporters (SVCTs). The kidney is one of a few organs that express both SVCT1 and SVCT2. Recent evidence suggests that accumulation of ascorbate may be different in tumour compared to normal tissue, but data on SVCT levels in tumours is sparse. Methods: The role of the two SVCT isoforms in ascorbate uptake in renal cell carcinoma (RCC) was investigated in vitro and in clinical samples. In three human RCC cell lines, we investigated SVCT protein levels and cellular location in response to ascorbate supplementation and withdrawal. In clinical RCC samples $(n=114)$, SVCT patterns of staining and protein levels were analysed and compared to ascorbate levels. Results: In cell culture, transporter levels and cellular location were not modified by ascorbate availability at any time up to 8h, although basal SVCT2 levels governed maximal ascorbate accumulation. In clinical samples, SVCT1 protein levels in papillary RCC (pRCC) were similar to matched normal renal cortex, but were increased in clear-cell RCC (ccRCC). Native SVCT2 (72 kDa) was significantly decreased in both pRCC and $c c R C C$ tissues compared to cortex $(p<0.01)$, whereas a modified form of SVCT2 $(100 \mathrm{kDa})$ was significantly increased $(p<0.001)$. There was no association between the transporters (SVCT1, native or modified SVCT2) and ascorbate concentrations in either normal or tumour tissues. SVCT1 and SVCT2 displayed diffuse cytoplasmic staining in both pRCC and $\mathrm{cCRCC}$ tumour cells, with cortex showing distinct membrane staining for
\end{abstract}


SVCT1. Conclusion: We observed a re-distribution of ascorbate transporters in tumour tissue compared to normal cortex and a shift from native to modified SVCT2 in cell culture and clinical samples. Data presented here show that SVCT protein levels do not appear to predict intracellular ascorbate accumulation in RCC.

(C) 2021 The Author(s). Published by Cell Physiol Biochem Press GmbH\&Co. KG

\section{Introduction}

Maintenance of whole-body ascorbate levels and distribution to different compartments is mediated primarily via sodium-dependent vitamin C transporters (SVCTs) [1]. SVCTs are members of the solute carrier gene family 23 (SLC23) [2], with three isoforms identified thus far; SVCT1 and SVCT2 that transport ascorbate, and the orphan transporter SVCT3 with still unknown function [3]. SVCT1 and SVCT2 are each comprised of 12 transmembrane domains and exert the cotransport of sodium and ascorbate in a ratio of 2:1 down an electrochemical sodium gradient which is maintained by $\mathrm{K} / \mathrm{Na}+$ exchange mechanisms [4]. SVCT2 additionally relies on $\mathrm{Ca}^{2+}$ and $\mathrm{Mg}^{2+}$ for its activity [4]. Expression of the different SVCT transport proteins is tissue and cell type-specific and is controlled by transcriptional regulation of SLC23 genes $[3,5]$ and post-translational regulation [6]. The exact control mechanisms are still not fully understood.

SVCT1 (encoded by SLC23A1) is expressed in the epithelial tissue of kidney, intestine, liver, lung and skin. SVCT1 is described as a low affinity, high capacity transporter with a Km in the range of $65-237 \mu \mathrm{M}$ and Vmax around $15 \mathrm{pmol} / \mathrm{min} /$ cell, which makes it capable of efficient uptake of ascorbate from the diet [7]. In comparison, SVCT2, encoded by SLC23A2, is expressed in almost every tissue and cell in the body and mediates whole body tissue uptake [5]. SVCT2 is characterised as a low capacity, high affinity transporter with a Vmax $\sim 1 \mathrm{pmol} /$ $\mathrm{min} /$ cell and $\mathrm{Km}$ of 8-69 $\mu \mathrm{M}$, that is suited to the maintenance of tissue homeostasis $[4,8]$.

The kidney plays a major role in the maintenance of whole-body ascorbate levels, with kidney epithelial cells expressing both SVCT isoforms [9]. In the renal cortex, SVCT1 is situated in the brush-border membrane of the proximal tubule where it mediates re-uptake of ascorbate from the glomerular filtrate [8]. Expression increases towards the distal regions of the tubules, and is hypothesised to be regulated by a decreasing ascorbate gradient along the tubular system [10]. SVCT2 is expressed in all cells of the kidney, including the proximal tubular epithelial cells, although at lower levels than SVCT1, and is located intracellularly [9]. Reports of SVCTs in cancer are sparse; only two studies have previously measured ascorbate transporter levels in human tumour tissue $[11,12]$, and SVCTs have never been investigated in renal cell carcinoma (RCC) tumours.

Worldwide, each year over 270,000 individuals are diagnosed with RCC, which is curable at an early stage but has limited treatment options when diagnosed at advanced stage, resulting in a 5-year survival of $<10 \%[13,14]$. Several histological types for RCC are defined, including clear cell RCC (ccRCC), which is the most aggressive and most frequent $(\sim 70 \%)$ type, and papillary RCC (pRCC) which is less common ( 15\%) [15].

Recent evidence suggests that accumulation of ascorbate may differ in tumour compared to normal tissue. We have shown that both ccRCCs and pRCCs contained higher ascorbate levels than normal cortex tissue [16], unlike other cancers that showed the reverse [12, 17, 18]. In the analysis of tissue from patients with colorectal, endometrial or breast cancer, no association between ascorbate levels measured in tumour and matched normal tissue was apparent [12,16-18]. Protein levels of SVCT1 was measured in human colon adenocarcinoma samples with similar levels to normal colon mucosa [11]. SVCT1 and SVCT2 together with ascorbate were measured in clinical breast tumour tissue, showing no clear association between transporter levels and ascorbate content [12]. No other human studies on SVCTs together with ascorbate in tumour tissue have been reported.

In this study we aimed to investigate the role of the two SVCTs in ascorbate uptake in RCC. SVCT protein levels and cellular location in response to ascorbate supplementation and withdrawal were determined in human ccRCC cell lines. SVCT patterns of staining and 


\section{\begin{tabular}{ll} 
Cellular Physiology & Cell Physiol Biochem 2021;55:553-568 \\
\hline DOl: 10.33594/000000435 & O 2021 The Author(s). Published by
\end{tabular} \begin{tabular}{ll|l} 
and Biochemistry & DOl: 10.33594/000000435 \\
\cline { 2 - 3 } Published online: 2 October 2021 & $\begin{array}{l}\text { O } 2021 \text { The Author(s). Published by } \\
\text { Cell Physiol Biochem Press GmbH\&Co. KG }\end{array}$ \\
\cline { 2 - 4 }
\end{tabular}}

protein levels were also analysed in clinical samples of renal cancer and associated normal renal cortex, and compared to measured tissue ascorbate levels.

\section{Materials and Methods}

\section{Materials}

All chemicals were obtained from Sigma-Aldrich (St Louis, USA), unless otherwise specified. Cell lines were obtained from the American Type Culture Collection (ATCC; Manassas, VA, USA). Bovine serum and antibiotics were from Life Technologies (Carlsbad, CA, USA). The following primary antibodies were used: anti-human SVCT1 (polyclonal rabbit, Aviva Systems, San Diego, CA, USA, OAAB09000), anti-human SVCT2 (polyclonal rabbit, Atlas Antibodies, Stockholm, Sweden, HPA052825) and anti- $\beta$-actin (monoclonal mouse, Sigma-Aldrich, A5316).

\section{Renal cell lines}

The human ccRCC cell lines Caki-1 (HTB-46), Caki-2 (HTB-47) and 786-0 were used at early passages in ATCC-recommended growth media (modified McCoy's 5A for Caki-1 and Caki-2, Dulbecco〉s Modified Eagle>s Medium (DMEM) for 786-0 cells) with 10\% foetal bovine serum and 1\% antibiotic-antimycotic solution (Sigma-Aldrich). All cells were regularly tested for mycoplasma by PCR [19].

\section{Ascorbate uptake and measurement}

Cells were grown to near confluence in multi-well plates. As growth media contains little or no ascorbate (McCoy's contains 5.4 $\mu \mathrm{M}$, DMEM contains $0 \mu \mathrm{M}$ ), freshly prepared sodium ascorbate was added to a final concentration of 50 or $500 \mu \mathrm{M}$. For measurements of intracellular ascorbate, cells were pelleted at a range of time points and processed for high-performance liquid chromatography with electrochemical detection (HPLC-ECD) analysis, as previously described [20]. Briefly, $0.54 \mathrm{M}$ perchloric acid containing diethylenetriamine penta-acetic acid was added to the cell extract, followed by ascorbate measurements using HPLC-ECD (Thermo Fisher Scientific, Waltham, MA, USA). Ascorbate concentration was assessed relative to standards (freshly prepared ascorbate, 1.25 to $40 \mu \mathrm{M}$ ).

\section{Patient samples and ethics}

Tissue samples, gifted to the Cancer Society Tissue Bank Christchurch (CSTB), were used with ethical approval from the University of Otago Human Ethics committee (reference code H14/020). This cohort of 73 ccRCC and 41 pRCC samples with matched renal cortex has previously been described [16]. In addition, a separate cohort of formalin-fixed, paraffin embedded sections and microarrays (15 pRCC and 63 ccRCC) were received from the CSTB and analysed by immunohistochemistry.

\section{Tissue preparation}

Frozen tissue samples were ground to a fine powder in liquid nitrogen, homogenized with RIPA buffer (50 mM Tris pH 8.0, $150 \mathrm{mM} \mathrm{NaCl}, 1 \%$ NP-40, 0.5\% sodium deoxylate, $0.1 \%$ SDS, with complete proteinase inhibitor cocktail, Roche, Basel, Switzerland), and DNA content was measured as an indication of the cellular content, as previously described [16].

\section{Antibody blocking}

The blocking peptide for SVCT1 (sc-9924 P) resembles amino acids 1 - 30 and the peptide for SVCT2 (sc-31991 P) corresponds to amino acids 183 - 212 of the protein sequence (Santa Cruz, Dallas, TX, USA). For competition assays, antibodies were incubated with 5 times excess of blocking peptides by weight for 1 hour at room temperature before incubation on the membrane.

\section{Western blotting}

For cell lines, lysates equivalent to $20 \mu \mathrm{g}$ protein, and for tissue, homogenates equivalent to $0.5 \mu \mathrm{g}$ DNA, were loaded per well. Proteins were separated on $4-12 \%$ Bis-Tris Plus SDS gels (Life Technologies, Carlsbad, CA, USA) and transferred to membranes, as described before [16]. Membranes were incubated with the following primary antibodies: anti-SVCT1 (1/1000), SVCT2 (1/500) and $\beta$-actin $(1 / 10000)$, 
with horseradish peroxidase labelled secondary goat anti-rabbit/anti-mouse antibodies (Dako, Glostrup, Denmark, P0448 and P0449). Protein bands were detected using the ECL Prime Western Blotting Detection Reagent (GE Healthcare, Chicago, USA), captured using the Alliance 4.7 imaging system and quantified using ImageJ.

\section{Immunofluorescence}

Cells seeded into 8-well chamber slides (Thermo Fisher Scientific, Waltham, MA, USA) were washed and fixed with $4 \%$ paraformaldehyde, permeabilised with $0.1 \%$ Triton X-100 and blocked with $1 \%$ bovine serum albumin. Transporters were detected using anti-SVCT2 at 1/500 and secondary fluorescent antibody (Donkey anti-rabbit IgG Alexa Fluor 598, 1/1000, Abcam, ab 150076). Cells were co-stained with CytoPainter Phalloiden-iFluor 488 (1/1000, Abcam, ab176753) and 4',6-diamidino-2-phenylindole (DAPI, Thermo Fisher Scientific). Slides were covered with Vectashield Antifade Mounting Medium (Vector Laboratories, Burlingame, CA, USA) and fluorescence assessed with an Axio Imager 2 using the ApoTome (Zeiss, Oberkochen, Germany).

\section{Immunohistochemistry}

Sections cut at $3 \mu \mathrm{m}$ were baked at $60^{\circ} \mathrm{C}$, deparaffinised and pressure heated for antigen retrieval in Tris-EDTA buffer with $0.05 \%$ Tween 20. Cell and Tissue Staining kits (R\&D Systems, Minneapolis, MN, USA) were used following manufacturer's recommendations to stain for SVCT1 (1/200) and SVCT2 (1/200); negative controls lacked primary antibodies.

\section{Statistical analyses}

Data were analysed using GraphPad Prism 5, using the Shapiro-Wilk test for normality. Differences between treatment conditions in cell culture were tested by One-way ANOVA with Dunnett's Multiple Comparison or Bonferroni post-test. Statistical significance between renal cortex and tumour data was tested with the non-parametric Wilcoxon matched-pairs signed rank test. Values of $\mathrm{p}<0.05$ were considered significant.

\section{Results}

\section{Ascorbate transporters in renal cell carcinoma cell lines}

Specificity of the antibodies against SVCT1 and SVCT2 was determined by pre-absorbing antibodies with blocking peptides that prevent binding to the target epitope [21]. For SVCT1, with a predicted molecular weight of $65 \mathrm{kDa}$, antibody blocking confirmed that the second immunoreactive band at $80 \mathrm{kDa}$ was non-specific (Fig. 1A). SVCT2 was detected at $72 \mathrm{kDa}$, its predicted molecular weight, but also at $\sim 100 \mathrm{kDa}$; both bands disappeared in the blocking assay and were therefore considered as specific for SVCT2 (Fig. 1A).

SVCT1 and SVCT2 proteins were confirmed in all three ccRCC cell lines (Fig. 1B). Protein levels of the two transporters varied between cell lines and between individual samples. 786-0 cells appeared to have the highest levels of SVCT1 and lowest levels of both immunoreactive forms of SVCT2 compared to the other two cell lines. Of the three cell lines, Caki-2 cells showed strongest immunoreactivity for SVCT2 (Fig. 1C).

Ascorbate accumulation and loss over time was measured in the ccRCC cells by HPLCECD. Our previous data had shown that all three cell lines reached intracellular ascorbate saturation when incubated with $500 \mu \mathrm{M}$ ascorbate [20]. Therefore, cells were exposed for $16 \mathrm{~h}$ to doses of ascorbate that achieve suboptimal $(50 \mu \mathrm{M})$ or optimal intracellular levels $(500 \mu \mathrm{M})$, followed by removal of ascorbate from the culture medium with sampling for up to $24 \mathrm{~h}$. Measurements were compared to cells that did not receive ascorbate $(0 \mu \mathrm{M})$, which had low/undetectable intracellular ascorbate concentrations, as expected (Fig. 2). Intracellular ascorbate levels in all three cell lines increased significantly over time with exposure to both $50 \mu \mathrm{M}$ and $500 \mu \mathrm{M}$ ascorbate, and dropped noticeably once ascorbate was withdrawn (dotted lines in Fig. 2). Supplementation with $50 \mu \mathrm{M}$ ascorbate resulted in a peak of $0.46 \mathrm{nmol} / 10^{6}$ cells at $8 \mathrm{~h}$ in $786-0$ cells, $1.85 \mathrm{nmol} / 10^{6}$ cells at $16 \mathrm{~h}$ in Caki- 1 , and 
Fig. 1. Protein levels of SVCT1 and SVCT2 in ccRCC cell lines in vitro. (A) SVCT antibodies were validated using blocking peptides. Antibodies for SVCT1 and SVCT2 were pre-absorbed with blocking peptides before incubation of the membranes. Western blots show Caki-1 cell lysates probed with the respective antibodies with $(+)$ or without $(-)$ blocking peptides. The specific band for SVCT1 was confirmed at $\sim 65$ kDa and SVCT2 was identified as a double band at $\sim 72$ and $100 \mathrm{kDa}$ (indicated by arrows). (B) Protein levels of SVCT1 and SVCT2 in 786-0, Caki-1 and Caki2 cells was analysed by Western blotting. $\beta$-actin was used as a loading control. (C) Quantification of relative protein levels of SVCT1 and SVCT2 (both size bands) in ccRCC cell lines. Mean \pm SD, $n=3$.

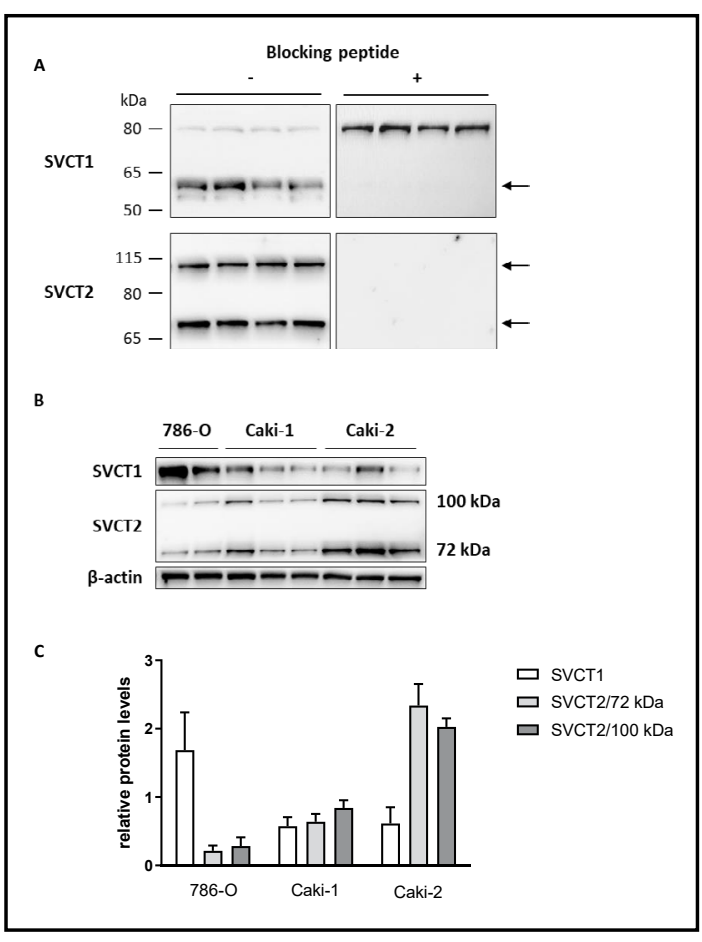

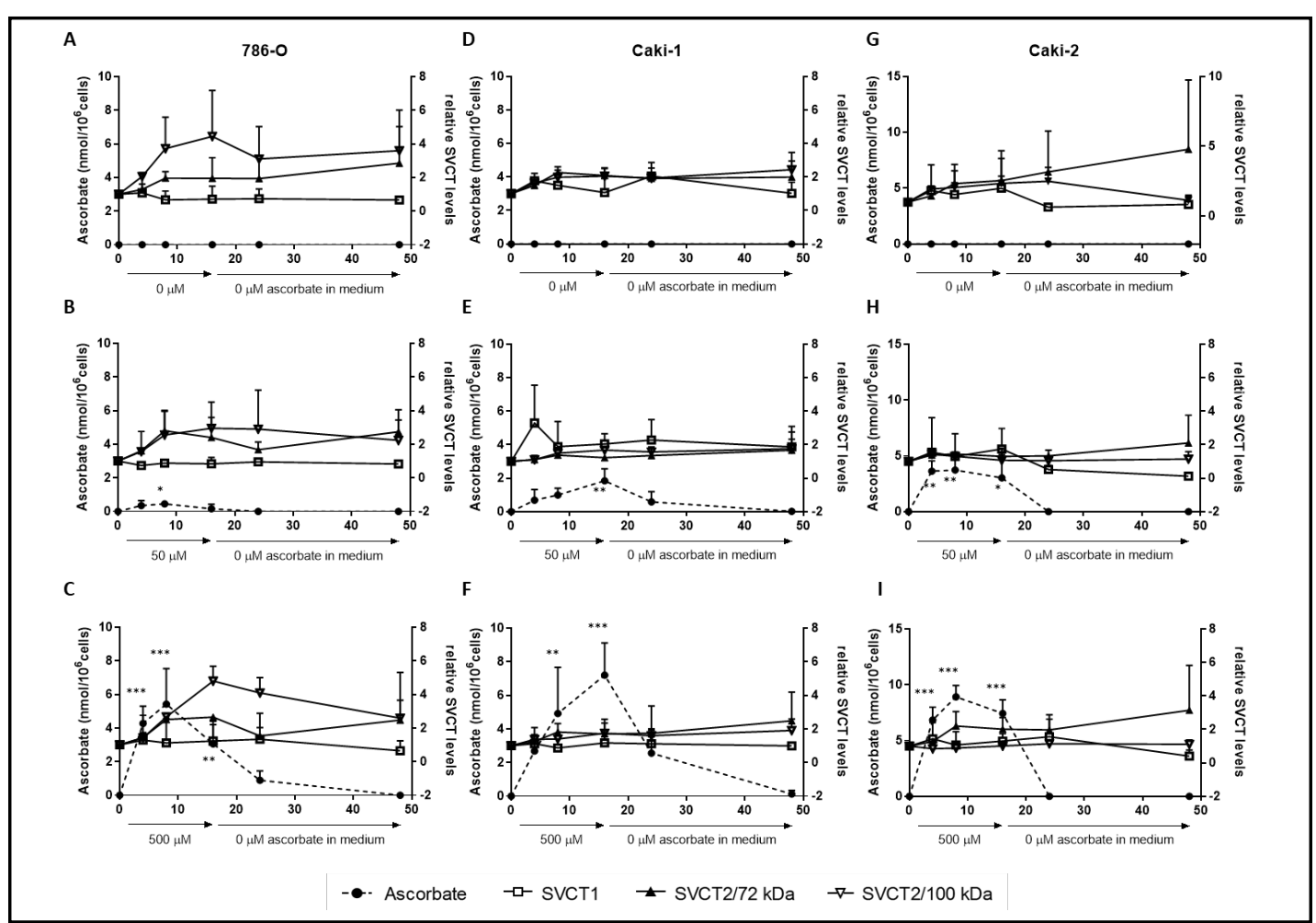

Fig. 2. Levels of ascorbate transporters in response to ascorbate over time in ccRCC cell lines. The ccRCC cells 786-0 (A-C), Caki-1 (D-F) and Caki-2 (G-I) were analysed for ascorbate, SVCT1 and SVCT2 (both bands). Cells were treated with $0 \mu \mathrm{M}(\mathrm{A}, \mathrm{D}, \mathrm{G}), 50 \mu \mathrm{M}(\mathrm{B}, \mathrm{E}, \mathrm{H})$ or $500 \mu \mathrm{M}$ ascorbate (C, F, I) for $16 \mathrm{~h}$ and then cultured without ascorbate for $24 \mathrm{~h}$. Ascorbate and protein levels of SVCT1 and SVCT2 was measured at indicated time points. Protein levels are relative to untreated cells at $0 \mathrm{~h}$, and did not change significantly by ascorbate addition or removal. Data are from three independent experiments and are presented as mean \pm SD. Statistical significance was determined by One-way ANOVA with Dunnett's Multiple Comparison Test; * $p<0.05$, ${ }^{* *} \mathrm{p}<0.01,{ }^{* * *} \mathrm{p}<0.001$. 
$3.73 \mathrm{nmol} / 10^{6}$ cells at $8 \mathrm{~h}$ in Caki- 2 cells. Higher supplementation (500 $\mu \mathrm{M}$ ascorbate) resulted in 2-11-fold higher intracellular concentrations at the same time points $(5.43,7.20$ and $8.92 \mathrm{nmol} / 10^{6}$ cells in 786-0, Caki- 1 and Caki- 2 cells, respectively).

Changes in transporter levels in response to varying ascorbate supply over time was monitored by Western blot (Fig. 2). Levels of SVCT1 and both immunoreactive forms of SVCT2 were variable over time in culture in the presence and absence of ascorbate. Neither transporter was significantly affected by the addition or removal of ascorbate (Fig. 2), with SVCT1 remaining particularly stable. However, in 786-0 cells, SVCT2 (100 kDa) levels tended to increase during exposure to $500 \mu \mathrm{M}$ ascorbate and to reduce during ascorbate withdrawal $(\mathrm{p}=0.081$; Fig. 2C).

When comparing SVCT protein levels from Fig. 1C and maximal ascorbate uptake in Fig. 2, it is noteworthy that the cell line (Caki-2) with the highest levels of SVCT2 proteins $(72$ and $100 \mathrm{kDa}$ ) also showed the highest maximal ascorbate accumulation following supplementation with $50 \mu \mathrm{M}$ and $500 \mu \mathrm{M}$ ascorbate. The cell line with the lowest levels SVCT2 proteins (786-0) also showed the lowest ascorbate accumulation, with Caki-1 showing intermediate protein and uptake characteristics. No such association was seen for SVCT1.

As there were no clear changes in overall protein levels of ascorbate transporters, possible differences in intracellular SVCT2 distribution were investigated. Immunofluorescence staining of SVCT2 was carried out in the three cell lines over a time period of either 5-60 min (short-term, Fig. 3) or 2-8 h (longer-term, Fig. 4) exposure to $500 \mu \mathrm{M}$ ascorbate. Immunofluorescence showed immunoreactivity of SVCT2 that appeared to be concentrated in cytoplasmic 'spots' (Fig. 3, Fig. 4). During early time-points (up to $1 \mathrm{~h}$ ) there appeared to be translocation to the nucleus or nuclear membrane in some cells (eg Caki-1 at $60 \mathrm{~min}$, Fig. 3, Fig. 4). However, there was no clear translocation to or from the plasma membrane at any time over $8 \mathrm{~h}$, despite the clear increase in intracellular ascorbate accumulation over this time period (Fig. 2 C, F, I). Co-staining of actin filaments with fluorescence labelled Phalloidin was used to evaluate cell shape. There was no apparent co-localisation of SVCT2 with Phalloidin, indicating a relative lack of SVCT2 at the plasma membrane.

\section{Ascorbate transporters in clinical samples of renal cell carcinoma}

Ascorbate transporter levels and location in clinical samples of renal cell carcinoma were investigated, and compared to ascorbate concentrations. SVCT1 protein was detected in both normal and tumour tissue (Fig. 5, Supplementary Fig. 1 - for all supplementary material see www.cellphysiolbiochem.com). Compared to matched normal renal cortex, protein levels of SVCT1 were similar in pRCC tumours, but were marginally increased in ccRCC tumours $(\mathrm{p}<0.05$; Fig. 5A and C).

In contrast, there appeared to be clear differences between SVCT2 levels in normal cortex and RCCs. Similar to in vitro, SVCT2 protein was detected as two specific bands; a non-specific band of intermediate size was ignored. The $100 \mathrm{kDa}$ band was considered as a modified form of SVCT2 and the second band at $72 \mathrm{kDa}$ as the native protein (Fig. 5B). Compared to normal cortex tissue there was a significant decrease of native SVCT2 (72 kDa) in pRCC and ccRCC tumour tissues ( $\mathrm{p}<0.01$ and $\mathrm{p}<0.001$, respectively; Fig. 5D). However, the modified form of SVCT2 (100 kDa) showed a significant increase in pRCC and ccRCC tumour samples compared to normal tissue ( $p<0.001$, Fig. 5E).

Our previous data had shown that renal tumours had significantly higher ascorbate levels compared to matched cortex tissue (pRCC tumour $12.48 \pm 1.13 \mathrm{mg} / 100 \mathrm{~g}$ tissue $(1.33$ - $31.76 \mathrm{mg} / 100 \mathrm{~g}$ ) vs cortex $6.99 \pm 0.46 \mathrm{mg} / 100 \mathrm{~g}$ tissue $(2.31-15.81 \mathrm{mg} / 100 \mathrm{~g})$; ccRCC tumour $13.15 \pm 1.67 \mathrm{mg} / 100 \mathrm{~g}$ tissue $(0.9-89.1 \mathrm{mg} / 100 \mathrm{~g})$ vs cortex $7.97 \pm 0.47 \mathrm{mg} / 100 \mathrm{~g}$ tissue (1.7 - $18.2 \mathrm{mg} / 100 \mathrm{~g}$ ) (mean $\pm \mathrm{SE}$ (min-max range) [16]). However, there was no association between any of the SVCTs (SVCT1, native and modified SVCT2 protein levels) and ascorbate concentrations in either normal or tumour tissues (Table 1). Specifically, despite detecting higher levels of modified SVCT2 in both tumour types compared to normal tissue, there was no association between protein levels of modified SVCT2 and ascorbate levels in tumour tissue in individual patients (Table 1). 
Cellular Physiology Cell Physiol Biochem 2021;55:553-568

\begin{tabular}{ll|l} 
and Biochemistry & $\begin{array}{l}\text { DOl: 10.33594/000000435 } \\
\text { Published online: } 2 \text { October } 2021\end{array}$ & $\begin{array}{l}\text { O } 2021 \text { The Author(s). Published by } \\
\text { Cell Physiol Biochem Press GmbH\&Co. KG }\end{array}$ \\
\cline { 2 - 3 }
\end{tabular}

Wohlrab et al.: Vitamin C Transporters in Renal Cell Carcinoma

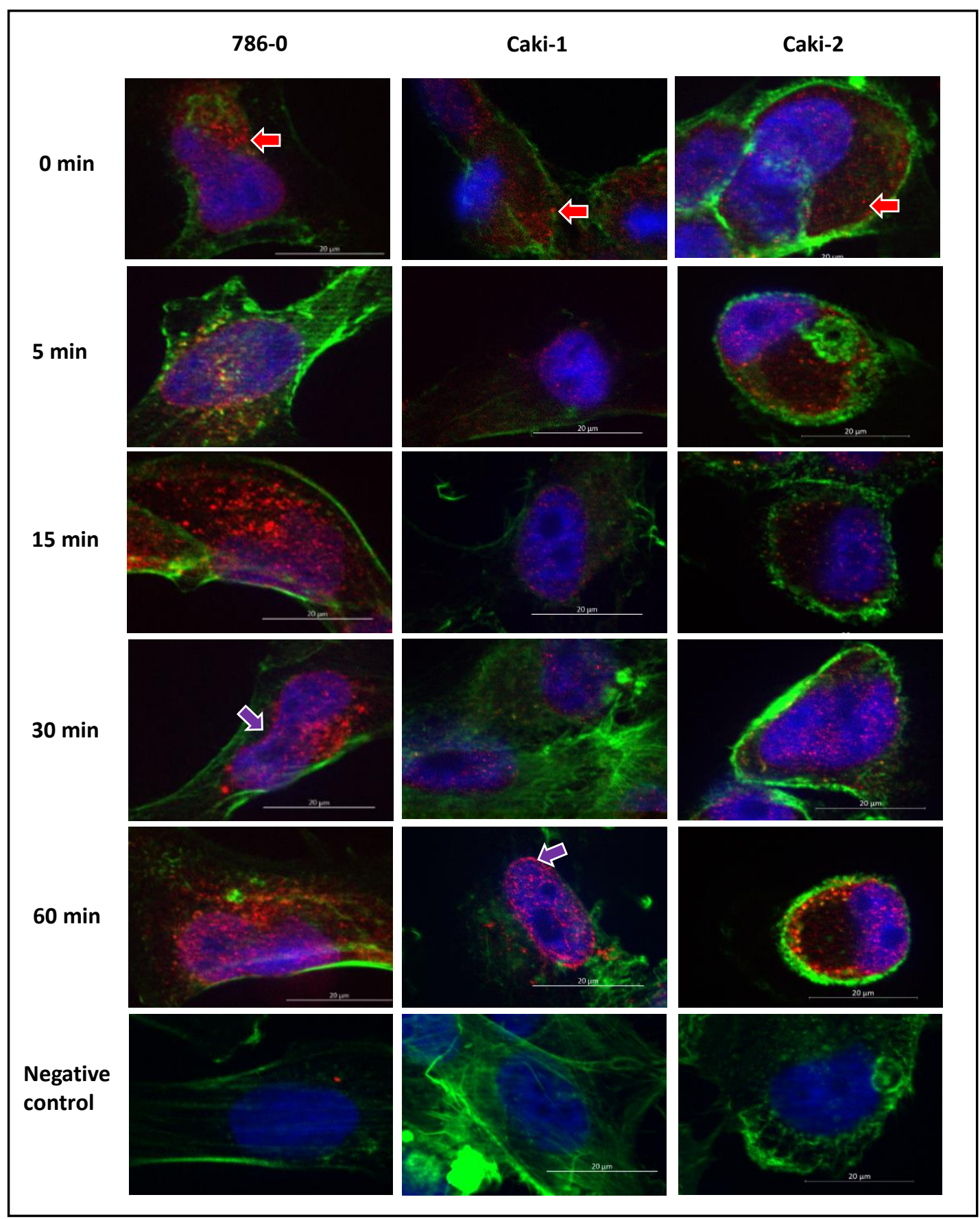

Fig. 3. Localisation of SVCT2 in 786-0, Caki-1 and Caki-2 cells during exposure to ascorbate. Cellular localisation of SVCT2 in response to extracellular ascorbate $(500 \mu \mathrm{M})$ was monitored for 5-60 min. Immunofluorescence images for SVCT2 (red) and Phalloidin (green to stain F-actin) of fixed cells were taken at indicated time points and are shown as merged images. Nuclei were visualised with DAPI (blue). Red arrows show examples of cytoplasmic spots, purple arrows illustrate nuclear localisation of SVCT2. 63x objective (oil), scale bar $=20 \mu \mathrm{m}$. Note that photos are enlarged and cropped to show individual cells of interest. 
Cellular Physiology Cell Physiol Biochem 2021;55:553-568

\begin{tabular}{ll|l} 
and Biochemistry & $\begin{array}{l}\text { DOl: 10.33594/000000435 } \\
\text { Published online: } 2 \text { October 2021 }\end{array}$ & $\begin{array}{l}\text { O } 2021 \text { The Author(s). Published by } \\
\text { Cell Physiol Biochem Press GmbH\&Co. KG }\end{array}$ \\
\cline { 2 - 3 } &
\end{tabular}

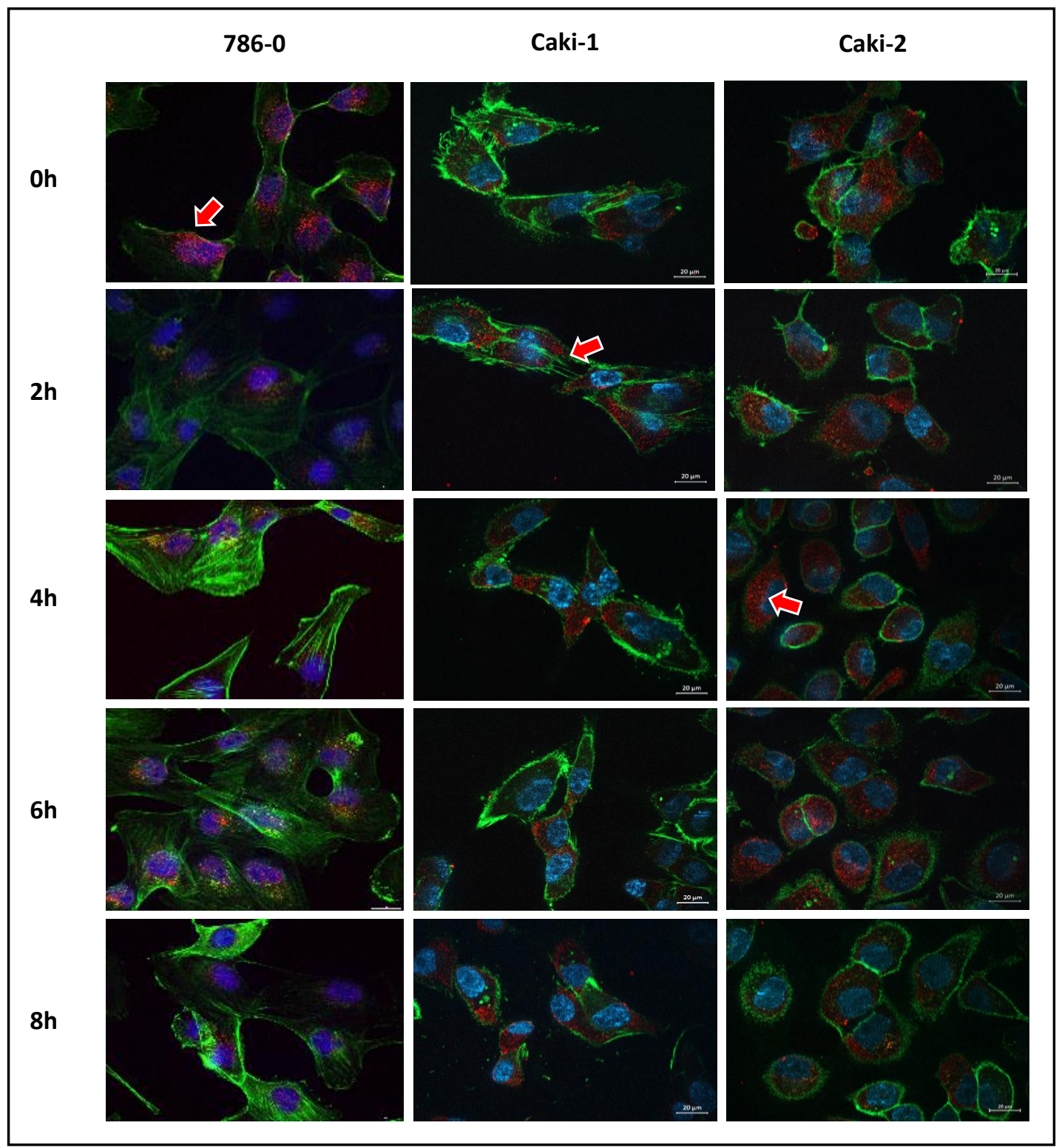

Fig. 4. Localisation of SVCT2 in 786-0, Caki-1 and Caki-2 cells during exposure to ascorbate. Cellular localisation of SVCT2 in response to extracellular ascorbate $(500 \mu \mathrm{M})$ was monitored for 2-8 h. Immunofluorescence images for SVCT2 (red) and Phalloidin (green to stain F-actin) of fixed cells were taken at indicated time points and are shown as merged images. Nuclei were visualised with DAPI (blue). Red arrows show examples of cytoplasmic spots, purple arrows illustrate nuclear localisation of SVCT2. 63x objective (oil), scale bar $=20 \mu \mathrm{m}$.

Table 1. Correlations between tissue ascorbate content and ascorbate transporter proteins. RCC renal cell carcinoma, r Spearman correlation, p significance, ascorbate concentrations previously reported [16]

\begin{tabular}{lccccc}
\hline & & \multicolumn{2}{c}{ Papillary RCC } & \multicolumn{2}{c}{ Clear cell RCC } \\
Transporter proteins & & $\begin{array}{c}\text { Renal cortex } \\
\mathrm{n}=38\end{array}$ & $\begin{array}{c}\text { Tumour } \\
\mathrm{n}=38\end{array}$ & $\begin{array}{c}\text { Renal cortex } \\
\mathrm{n}=71\end{array}$ & $\begin{array}{c}\text { Tumour } \\
\mathrm{n}=71\end{array}$ \\
\hline \multirow{2}{*}{ SVCT1 } & $\mathrm{r}$ & -0.028 & -0.03 & 0.051 & -0.15 \\
& $\mathrm{p}$ & 0.869 & 0.863 & 0.671 & 0.215 \\
SVCT2/72 kDa & $\mathrm{r}$ & -0.051 & -0.213 & -0.161 & 0.012 \\
& $\mathrm{p}$ & 0.761 & 0.199 & 0.179 & 0.924 \\
SVCT2/100 kDa & $\mathrm{r}$ & -0.002 & -0.023 & 0.089 & -0.054 \\
& $\mathrm{p}$ & 0.992 & 0.892 & 0.458 & 0.655 \\
\hline
\end{tabular}


Fig. 5. Ascorbate transporter levels in RCC tumour tissue compared to renal cortex. Representative Western blots for normal renal cortex (N) and tumour (T) tissue from papillary RCC and clear cell RCC for SVCT1 (A) and SVCT2 (B) are shown together with $\beta$-actin as a loading control. Relative protein levels are band densities referenced to a control sample which was loaded on each gel $(+$, pRCC tumour sample). Non-specific bands are marked with an asterisk. (C) Levels of SVCT1 were unchanged in pRCC and increased in ccRCC tumours compared to normal renal cortex. (D) In both RCC subtypes, levels of the $72 \mathrm{kDa}$ form of SVCT2 were significantly decreased in tumour compared to normal tissue. (E) The 100 kDa form of SVCT2 was increased in both pRCC and ccRCC tumour tissue. Statistical significance was assessed with the Wilcoxon matched-pairs signed rank test; $p R C C n=38$; $c$ RCC $n=71$; Mean \pm SEM; ${ }^{*} p<0.05$, ${ }^{* *} \mathrm{p}<0.01,{ }^{* * *} \mathrm{p}<0.001$.

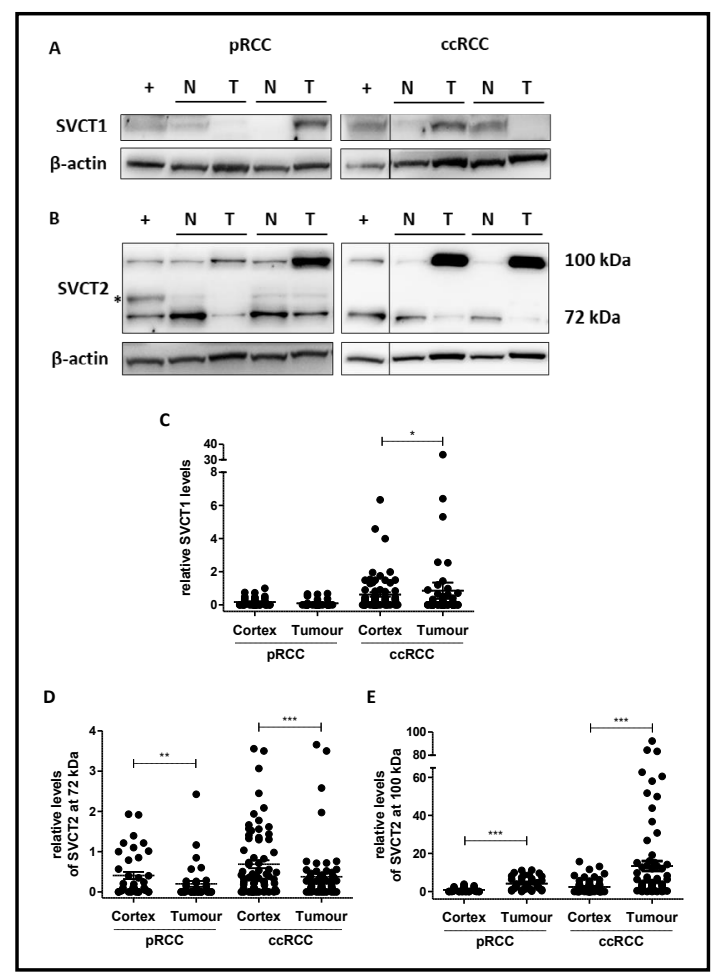

SVCT location within renal tissue was investigated using tissue microarrays of 15 pRCC and 63 ccRCC cores, as well as full sections of normal renal cortex from two patients without kidney cancer (Fig. 6, Supplementary Fig. 2). In tumour cores, SVCT1 displayed diffuse cytoplasmic staining in both pRCC and ccRCC cells (Fig. 6), with 88\% of pRCC and $85 \%$ of ccRCC cores staining positive. In contrast, in the normal renal cortex, SVCT1 showed strong apical membrane staining of the proximal tubular epithelial cells but no SVCT1 staining in distal tubules or corpuscles (Fig. 6). As previously described, proximal tubules in normal tissue displayed non-specific staining due to endogenous biotin and peroxidase activity [22, 23], which was not evident in tumour cores. Immunoreactivity of SVCT2 was detected in all tumour cores and throughout the normal cortex, with diffuse cytoplasmic staining (Fig. 6). Both transporters were also detected in infiltrating immune cells (Fig. 6). As ascorbate content was not available for most tumours of this TMA cohort, associations between staining pattern and ascorbate could not be performed.

\section{Discussion}

We report levels and localisation of ascorbate transporters and their correlation to ascorbate concentrations in renal cell carcinoma cell lines and clinical samples. Although RCC cell lines with lower basal levels of SVCT2 showed lower ascorbate accumulation and the cell line with higher SVCT2 levels had higher ascorbate accumulation, there was no clear association between changes in ascorbate concentrations and protein levels of SVCT1 and SVCT2 in cell lines in vitro. Neither did we observe clear associations between transporter protein levels and ascorbate in clinical tumour samples. SVCT1 protein was marginally higher in ccRCC compared to normal renal cortex, whereas native SVCT2 protein was lower. The modified SVCT2 protein was significantly higher in both pRCC and ccRCC compared to normal cortex tissue.

Reports on the effect of ascorbate supplementation on changes in SVCT expression are conflicting. In the human bronchial epithelium, SVCT2 protein levels inversely correlate 


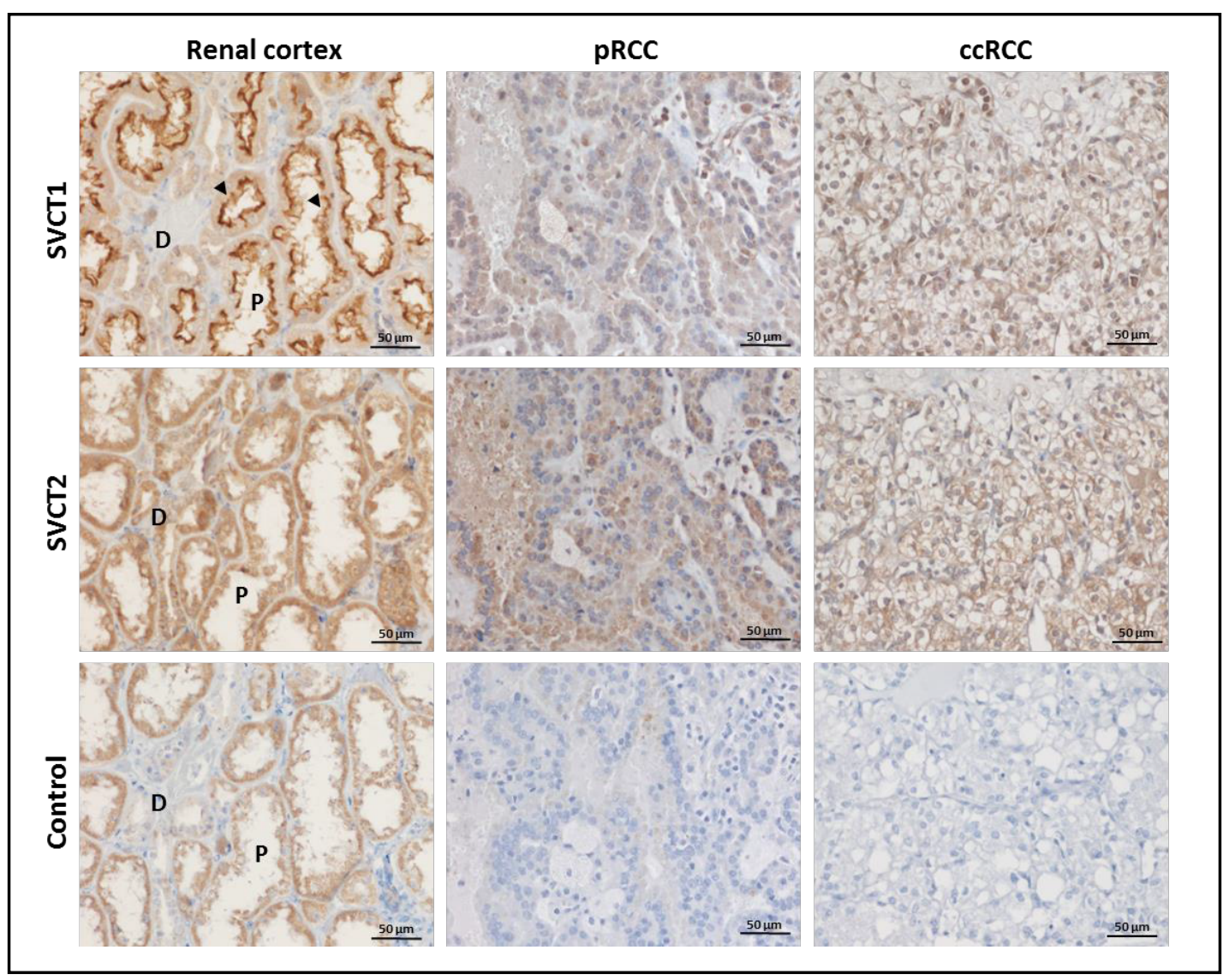

Fig. 6. Immunohistochemical detection of ascorbate transporters in renal cortex and RCC tumour tissue. Tissue sections of human renal cortex, pRCC and ccRCC tumours were analysed for ascorbate transporter distribution by immunohistochemistry. In normal renal cortex tissue, SVCT1 was localised to the apical membrane of proximal tubular epithelial cells (P; indicated with arrowheads) and was absent in distal tubules (D). In pRCC and ccRCC tissue, staining of SVCT1 was cytoplasmic. Immunoreactivity of SVCT2 was seen in the cytoplasm of both cortex and tumour tissue. The negative control (no primary antibody) of renal cortex showed marked unspecific background staining that was especially strong in proximal tubular cells. No staining was seen in the negative controls of tumour tissue. Representative photos for SVCT1, SVCT2 and control are taken from serial sections of the same location; 20x objective, scale bar $=50 \mu \mathrm{m}$.

with ascorbate concentration in the respiratory tract lining fluid [24]. Long-term exposure of human skin fibroblasts to ascorbate increased mRNA expression of SVCT2 [25], although protein was not measured. On the other hand, in human colon carcinoma cells, high concentrations of ascorbate down-regulated SVCT1 mRNA expression in vitro [26]. A pharmacokinetic study in tumour-bearing Gulo(-/-) mice has shown that in response to a single high dose administration of ascorbate, there was a prolonged presence of ascorbate in the tumour compared to plasma and liver, where ascorbate levels reduced rapidly [27]. In these mouse tumours, protein levels of SVCT1 were low with little variation following ascorbate administration, whereas SVCT2 protein levels varied over time with some evidence of increase with increasing ascorbate over time [27]. Gene expression of SVCT1 and SVCT2 is regulated by transcription factors, such as NF- $\kappa B$ [28] and suppressed by p53 [29], and via different epigenetic mechanisms (DNA methylation and histone modifications) [30]. In the ccRCC cell lines used in this study, protein levels of both transporter isoforms were highly variable and largely independent of intra- and extracellular ascorbate. Only in 786-0 cells (mutant p53) did the levels of SVCT2 (100 kDa) tend to be elevated during exposure to ascorbate. Ascorbate has been shown to induce activity of the ten-eleven translocase 
demethylase enzymes leading to DNA demethylation [31], which could potentially be involved in epigenetic regulation of the expression of transporters in these cells.

Different molecular weights have been reported for both SVCT isoforms, and in our study, blocking peptides confirmed SVCT1 as a $65 \mathrm{kDa}$ protein and SVCT2 as two specific bands of $72 \mathrm{kDa}$ and $100 \mathrm{kDa}$. This size shift for SVCT 2 can potentially be explained by N-glycosylation adding multiple sugar chains to the transporter [32]. Glycosylation is known to be necessary for function and trafficking of the transporter between cellular compartments [32-34]. A shift of more than $20 \mathrm{kDa}$ in molecular weight due to glycosylation is unusual, but a similar band shift for human SVCT2 has been reported before, which could be reversed with a glycosylation inhibitor [33]. Glycosylation of SVCT1 has also been reported [33], but was not observed in our study. Alternatively, ascorbate transporters are also regulated via posttranslational phosphorylation [6,32], but glycosylation is the more likely reason for the observed SVCT2 $100 \mathrm{kDa}$ species due to the magnitude of the shift, but this needs to be confirmed.

Subcellular localisation of the transporters in non-cancerous cells has been intensely studied. SVCT2 protein is localised in mitochondria, intracellular vesicles, the endoplasmic reticulum and the Golgi apparatus [35-37], and has different kinetic properties depending on its location [35]. Mitochondrial SVCT2 has been proposed to function as a low-affinity transporter due to differences in intracellular sodium and potassium concentrations, enabling transport into intracellular organelles [37]. Transporters may normally reside elsewhere but rapidly traffic to the membrane upon stimulation. In neurons in culture, SVCT2 translocated from the cytoplasm to the plasma membrane as extracellular ascorbate concentration increased [36]. Based on data from cancer (HeLa) and non-cancer cells (HEK293), the same group suggested that there are two responses to ascorbate: an acute response within 5 - 10 minutes, leading to recycling of transporters that are in close proximity to the membrane through endocytosis; and a post-acute response at 30 - 60 minutes, where glycosylated SVCT2 is transported from the endoplasmic reticulum to the plasma membrane [34]. We did not see clear changes in compartmentalisation of SVCT2 in ccRCC cells upon ascorbate addition, even at the early time points, with the exception of a potential shift towards the nucleus or nuclear membrane. The in vitro staining patterns observed in our study are largely consistent with predominant localisation of the SVCTs in vesicles or mitochondria, with relatively lower levels of expression at the plasma membrane. These intracellular locations may be associated with known functional requirements, such as the support of transcription factor activity and epigenetic regulation $[31,38]$.

The kidney has a unique distribution of ascorbate transporters, with SVCT1 situated in the brush-border membrane of proximal tubule cells mediating renal reabsorption, and with SVCT2 expressed basolaterally in all cells of the kidney except the proximal tubule $[8,39,40]$. In our clinical tissues, SVCT1 showed membrane staining of the proximal but not distal tubular epithelial cells in the normal renal cortex, as expected. However, no membrane staining for SVCT1 was seen in either pRCC or ccRCC tumours, where diffuse cytoplasmic staining was evident. We found cytoplasmic localisation of SVCT2 in epithelial cells of normal renal cortex including the proximal tubule, contrasting previous reports $[39,41]$. In the tumour samples, SVCT2 was not located at the cell membrane, but rather in cytoplasmic aggregates or diffusely in the cytoplasm. This observation is in line with the above-mentioned in vitro studies [34-37]. Overall, these data suggest that ascorbate can be variously compartmentalised within the cell, and SVCT distribution may differ between noncancerous and cancer cells.

Availability of ascorbate to tumour cells is often limited due to decreased plasma levels in patients with cancer [42-44] and inadequate tissue vascularisation and poor perfusion [45]. The fact that renal tumours had increased ascorbate levels [16] may indicate an increase in active ascorbate transport, and we measured higher levels of the modified SVCT2 $(100 \mathrm{kDa})$. This observed shift from an unmodified to a modified form of SVCT2 (potentially glycosylated and more active), together with re-distribution of ascorbate transporters in tumour tissue compared to normal cortex, and a shift from SVCT1 to SVCT2, could result 
in altered transporter function and ascorbate uptake dynamics in RCC. These changes may influence the observed increased ascorbate content in tumour compared to normal tissue. However, at the individual patient level, transporter levels did not correlate with ascorbate levels in tumour or normal tissues. As dietary ascorbate intake in this patient cohort was not known, and neither was ascorbate content of their plasma, this lack of correlation remains to be further explored. We observed that ccRCCs had high numbers of infiltrating immune cells, confirming previous studies $[46,47]$, which could result in elevated ascorbate measurements of whole tissue lysates of some tumours as immune cells can concentrate up to 100-times more ascorbate compared to plasma levels $[48,49]$.

Alternative options for ascorbate accumulation have been proposed. The oxidised form of ascorbate, dehydroascorbate (DHA), can be accumulated through facilitated diffusion via glucose transporters in competition with glucose $[50,51]$. Once in the cell, DHA gets rapidly reduced to ascorbate by dehydroascorbate reductase. However, under physiological conditions, at neutral $\mathrm{pH}$, DHA rapidly hydrolyses to diketogulonic acid and is subsequently lost $[5,52]$. Therefore, DHA levels in plasma are very low or undetectable $(<10 \%$ of total ascorbate) in correctly handled samples [53]. Our previous studies showed no association between glucose transporter 1 with ascorbate concentrations in either clinical RCC samples or cell lines in vitro $[16,20]$.

Increasingly patients with cancer choose to receive high-dose ascorbate infusions [54], often outside of regular clinical care and oversight. Outcomes are not monitored and there is still no robust evidence to support this practice. However, the newly discovered functions of ascorbate that include a proposed prooxidant activity and enzyme cofactor function have demonstrated potential anticancer activities $[38,55,56]$. Current clinical trials are evaluating high-dose ascorbate in combination with anticancer agents in ccRCC, with no outcomes yet reported [57]. Our data here demonstrates that RCCs accumulate ascorbate at high levels with dietary intake and that SVCT levels were not modified by ascorbate supply in vitro, but how high-dose infusion would modify tumour levels is unknown.

\section{Conclusion}

In summary, our data indicate that SVCT isoforms and protein modifications may differ between tumour and normal renal tissue. The SVCTs appear to be predominantly located at intracellular sites, and expression levels do not change appreciably in the presence or absence of ascorbate. Hence there is not a simple relationship between tissue ascorbate content and SVCT levels, and our data indicate that SVCT protein levels do not predict intracellular ascorbate accumulation in RCC. Also, ascorbate supply may not modify SVCT protein levels and there may be complex dynamic changes in sub-cellular localisation of the transporter, but any functional impact of such changes in renal cancer cells is unknown.

\section{Acknowledgements}

We thank the Cancer Society Tissue Bank (CSTB) in Christchurch for providing patient samples. CSTB is supported by the Canterbury West Coast Division of the Cancer Society of New Zealand.

\section{Author Contributions}

GD conceived the study, CW, EB and MN collected the data, MV and EP helped analyse the data, and CW composed the draft manuscript. MV, BR and GD edited and refined the manuscript. All authors finalized the manuscript. GD, MV and BR obtained funding for the study. 


\section{\begin{tabular}{ll} 
Cellular Physiology & Cell Physiol Biochem 2021;55:553-568 \\
\hline DOl: 10.33594/000000435 & O 2021 The Author(s). Published by
\end{tabular} \begin{tabular}{ll} 
and Biochemistry Published online: 2 October 2021 & $\begin{array}{l}\text { DOI: } 2021 \text { The Author(s). Published by } \\
\text { Cell Physiol Biochem Press GmbH\&Co. KG }\end{array}$ \\
\hline
\end{tabular}}

Funding Sources

This study was supported by the Cancer Research Trust NZ (GOT/1644/RPG), the Mackenzie Charitable Foundation (GD and EP), the Vitamin C for Cancer Trust (EB), the University of Otago (PhD Scholarship for CW) and the Centre for Translational Cancer Research, University of Otago (Summer studentship for MN).

\section{Statement of Ethics}

Human tissue samples were collected by the Cancer Society Tissue Bank (CSTB) Christchurch and used with ethical approval from the University of Otago Human Ethics committee (reference code H14/020). Use of samples for this study was approved by the CSTB board. All CSTB donors gave informed written consent for the use of their samples for research.

\section{Disclosure Statement}

The authors have no conflicts of interest to declare.

\section{References}

1 Tsukaguchi H, Tokui T, Mackenzie B, Berger UV, Chen XZ, Wang Y, Brubaker RF, Hediger MA: A family of mammalian Na+-dependent L-ascorbic acid transporters. Nature 1999;399:70-75.

2 Eck P, Erichsen HC, Taylor JG, Yeager M, Hughes AL, Levine M, Chanock S: Comparison of the genomic structure and variation in the two human sodium-dependent vitamin C transporters, SLC23A1 and SLC23A2. Hum Genet 2004;115:285-294.

3 Bürzle M, Suzuki Y, Ackermann D, Miyazaki H, Maeda N, Clémençon B, Burrier R, Hediger MA: The sodiumdependent ascorbic acid transporter family SLC23. Mol Aspects Med 2013;34:436-454.

4 Godoy A, Ormazabal V, Moraga-Cid G, Zúñiga FA, Sotomayor P, Barra V, Vasquez O, Montecinos V, Mardones L, Guzmán C, Villagrán M, Aguayo LG, Oñate SA, Reyes AM, Cárcamo JG, Rivas CI, Vera JC: Mechanistic insights and functional determinants of the transport cycle of the ascorbic acid transporter SVCT2. Activation by sodium and absolute dependence on bivalent cations. J Biol Chem 2007;282:615-624.

5 Michels AJ, Hagen TM, Frei B: Human genetic variation influences vitamin C homeostasis by altering vitamin $C$ transport and antioxidant enzyme function. Annu Rev Nutr 2013;33:45-70.

6 Lindblad M, Tveden-Nyborg P, Lykkesfeldt J: Regulation of vitamin C homeostasis during deficiency. Nutrients 2013;5:2860-2879.

7 Savini I, Rossi A, Pierro C, Avigliano L, Catani MV: SVCT1 and SVCT2: key proteins for vitamin C uptake. Amino Acids 2008;34:347-355.

8 Daruwala R, Song J, Koh WS, Rumsey SC, Levine M: Cloning and functional characterization of the human sodium-dependent vitamin C transporters hSVCT1 and hSVCT2. FEBS Lett 1999;460:480-484.

9 Nualart F, Castro T, Low M, Henríquez JP, Oyarce K, Cisternas P, García A, Yáñez AJ, Bertinat R, Montecinos VP, García-Robles MA: Dynamic expression of the sodium-vitamin C co-transporters, SVCT1 and SVCT2, during perinatal kidney development. Histochem Cell Biol 2013;139:233-247.

10 Castro T, Low M, Salazar K, Montecinos H, Cifuentes M, Yáñez AJ, Slebe JC, Figueroa CD, Reinicke K, de los Angeles García M, Henriquez JP, Nualart F: Differential distribution of the Sodium-vitamin C cotransporter- 1 along the proximal tubule of the mouse and human kidney. Kidney Int 2008;74:12781286.

11 Aguilera O, Muñoz-Sagastibelza M, Torrejón B, Borrero-Palacios A, Del Puerto-Nevado L, Martínez-Useros J, Rodriguez-Remirez M, Zazo S, García E, Fraga M, Rojo F, García-Foncillas J: Vitamin C uncouples the Warburg metabolic switch in KRAS mutant colon cancer. Oncotarget 2016;7:47954-47965.

12 Campbell EJ, Dachs GU, Morrin HR, Davey VC, Robinson BA, Vissers MCM: Activation of the hypoxia pathway in breast cancer tissue and patient survival are inversely associated with tumor ascorbate levels. BMC Cancer 2019;19:307. 
13 Srinivasan R, Ricketts CJ, Sourbier C, Linehan WM: New strategies in renal cell carcinoma: targeting the genetic and metabolic basis of disease. Clin Cancer Res 2015;21:10-17.

14 Incorvaia L, Bronte G, Bazan V, Badalamenti G, Rizzo S, Pantuso G, Natoli C, Russo A: Beyond evidence-based data: scientific rationale and tumour behavior to drive sequential and personalized therapeutic strategies for the treatment of metastatic renal cell carcinoma. Oncotarget 2016;7:21259-21271.

15 Znaor A, Lortet-Tieulent J, Laversanne M, Jemal A, Bray F: International variations and trends in renal cell carcinoma incidence and mortality. Eur Urol 2015;67:519-530.

16 Wohlrab C, Vissers MCM, Phillips E, Morrin H, Robinson BA, Dachs GU: The association between ascorbate and the hypoxia-inducible factors in human renal cell carcinoma requires a functional von Hippel-Lindau protein. Front Oncol 2018;8:574.

17 Kuiper C, Molenaar IG, Dachs GU, Currie MJ, Sykes PH, Vissers MC: Low ascorbate levels are associated with increased hypoxia inducible factor-1 activity and an aggressive tumor phenotype in endometrial cancer. Cancer Res 2010;70:5749-5758.

18 Kuiper C, Dachs GU, Munn D, Currie MJ, Robinson BA, Pearson JF, Vissers MC: Increased tumor ascorbate is associated with extended disease-free survival and decreased hypoxia-inducible factor- 1 activation in human colorectal cancer. Front Oncol 2014;4:10.

19 Timenetsky J, Santos LM, Buzinhani M, Mettifogo E: Detection of multiple mycoplasma infection in cell cultures by PCR. Braz J Med Biol Res 2006;39:907-914.

20 Wohlrab C, Kuiper C, Vissers MC, Phillips E, Robinson BA, Dachs GU: Ascorbate modulates the hypoxic pathway by increasing intracellular activity of the HIF hydroxylases in renal cell carcinoma cells. Hypoxia (Auckl) 2019;7:17-31.

21 García Mde L, Salazar K, Millán C, Rodríguez F, Montecinos H, Caprile T, Silva C, Cortes C, Reinicke K, Vera JC, Aguayo LG, Olate J, Molina B, Nualart F: Sodium vitamin C cotransporter SVCT2 is expressed in hypothalamic glial cells. Glia 2005;50:32-47.

22 Bussolati G, Gugliotta P, Volante M, Pace M, Papotti M: Retrieved endogenous biotin: a novel marker and a potential pitfall in diagnostic immunohistochemistry. Histopathology 1997;31:400-407.

23 El-Far MA, Bakr MA, Farahat SE, Abd El-Fattah EA: Glutathione peroxidase activity in patients with renal disorders. Clin Exp Nephrol 2005;9:127-131.

24 Larsson N, Rankin GD, Bicer EM, Roos-Engstrand E, Pourazar J, Blomberg A, Mudway IS, Behndig AF: Identification of vitamin $\mathrm{C}$ transporters in the human airways: a cross-sectional in vivo study. BMJ Open 2015;5:e006979.

25 Kishimoto Y, Saito N, Kurita K, Shimokado K, Maruyama N, Ishigami A: Ascorbic acid enhances the expression of type 1 and type 4 collagen and SVCT2 in cultured human skin fibroblasts. Biochem Biophys Res Commun 2013;430:579-584.

26 MacDonald L, Thumser AE, Sharp P: Decreased expression of the vitamin C transporter SVCT1 by ascorbic acid in a human intestinal epithelial cell line. Br J Nutr 2002;87:97-100.

27 Campbell EJ, Vissers MCM, Wohlrab C, Hicks KO, Strother RM, Bozonet SM, Robinson BA, Dachs GU: Pharmacokinetic and anti-cancer properties of high dose ascorbate in solid tumours of ascorbatedependent mice. Free Radic Biol Med 2016;99:451-462.

28 Portugal CC, da Encarnação TG, Socodato R, Moreira SR, Brudzewsky D, Ambrósio AF, Paes-de-Carvalho R: Nitric oxide modulates sodium vitamin $C$ transporter 2 (SVCT-2) protein expression via protein kinase $G$ (PKG) and nuclear factor-kB (NF-kB). J Biol Chem 2012;287:3860-3872.

29 Kim EH, Koh DI, Ryu YS, Park SS, Hong SW, Moon JH, Shin JS, Kim MJ, Kim DY, Hong JK, Jeong HR, Yun H, Shin JY, Kim J, Park YS, Kim DM, Jin DH: Role of p53 in transcriptional repression of SVCT2. Mol Biol Rep 2021;48:1651-1658.

30 Qiao H, May JM: CpG methylation at the USF-binding site mediates cell-specific transcription of human ascorbate transporter SVCT2 exon 1a. Biochem J 2011;440:73-84.

31 Shenoy N, Bhagat T, Nieves E, Stenson M, Lawson J, Choudhary GS, Habermann T, Nowakowski G, Singh R, Wu X, Verma A, Witzig TE: Upregulation of TET activity with ascorbic acid induces epigenetic modulation of lymphoma cells. Blood Cancer J 2017;7:e587.

32 Subramanian VS, Marchant JS, Reidling JC, Said HM: N-Glycosylation is required for Na+-dependent vitamin C transporter functionality. Biochem Biophys Res Commun 2008;374:123-127.

33 Liang WJ, Johnson D, Ma LS, Jarvis SM, Wei-Jun L: Regulation of the human vitamin C transporters expressed in COS-1 cells by protein kinase C [corrected]. Am J Physiol Cell Physiol 2002;283:C1696-1704. 


\section{Cellular Physiology Cell Physiol Biochem 2021;55:553-568

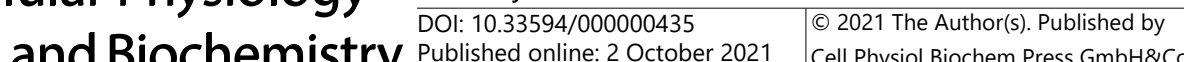 and Biochemistry Published online: 2 October 2021 Cell Physiol Biochem Press GmbH\&Co. KG \\ Wohlrab et al.: Vitamin C Transporters in Renal Cell Carcinoma}

34 Covarrubias-Pinto A, Acuña AI, Boncompain G, Papic E, Burgos PV, Perez F, Castro MA: Ascorbic acid increases SVCT2 localization at the plasma membrane by accelerating its trafficking from early secretory compartments and through the endocytic-recycling pathway. Free Radic Biol Med 2018;120:181-191.

35 Subramanian VS, Marchant JS, Said HM: Molecular determinants dictating cell surface expression of the human sodium-dependent vitamin C transporter-2 in human liver cells. American Journal of Physiology. Am J Physiol Gastrointest Liver Physiol 2010;298:G267-G274.

36 Acuña AI, Esparza M, Kramm C, Beltrán FA, Parra AV, Cepeda C, Toro CA, Vidal RL, Hetz C, Concha II, Brauchi S, Levine MS, Castro MA: A failure in energy metabolism and antioxidant uptake precede symptoms of Huntington's disease in mice. Nat Commun 2013;4:2917.

37 Muñoz-Montesino C, Roa FJ, Peña E, González M, Sotomayor K, Inostroza E, Muñoz CA, González I, Maldonado M, Soliz C, Reyes AM, Vera JC, Rivas CI: Mitochondrial ascorbic acid transport is mediated by a low-affinity form of the sodium-coupled ascorbic acid transporter-2. Free Radic Biol Med 2014;70:241254.

38 Vissers MCM, Das AB: Potential Mechanisms of Action for Vitamin C in Cancer: Reviewing the Evidence. Front Physiol 2018;9:809.

39 Eck P, Kwon O, Chen S, Mian O, Levine M: The human sodium-dependent ascorbic acid transporters SLC23A1 and SLC23A2 do not mediate ascorbic acid release in the proximal renal epithelial cell. Physiol Rep 2013;1:e00136.

40 Eck PK, Corpe C, Levine MA: Temporo-spacial microanatomical distribution of the murine sodiumdependent ascorbic acid transporters Slc23a1 and Slc23a2 in the kidney throughout development. Biochem Cell Biol 2017;95:421-427.

41 Boyer JC, Campbell CE, Sigurdson WJ, Kuo SM: Polarized localization of vitamin C transporters, SVCT1 and SVCT2, in epithelial cells. Biochem Biophys Res Commun 2005;334:150-156.

42 Anthony HM, Schorah CJ: Severe hypovitaminosis C in lung cancer patients: the utilization of vitamin C in surgical repair and lymphocyte-related host resistance. Br J Cancer 1982;46:354-367.

43 Mayland CR, Bennett MI, Allan K: Vitamin C deficiency in cancer patients. Pall Med 2005;19:17-20.

44 White R, Nonis M, Pearson JF, Burgess E, Morrin HR, Pullar JM, Spencer E, Vissers MCM, Robinson BA, Dachs GU: Low Vitamin C Status in Patients with Cancer Is Associated with Patient and Tumor Characteristics. Nutrients 2020;12:2338.

45 Kuiper C, Vissers MC, Hicks KO: Pharmacokinetic modeling of ascorbate diffusion through normal and tumor tissue. Free Radic Biol Med 2014;77:340-352.

46 Singer K, Kastenberger M, Gottfried E, Hammerschmied CG, Büttner M, Aigner M, Seliger B, Walter B, Schlösser H, Hartmann A, Andreesen R, Mackensen A, Kreutz M: Warburg phenotype in renal cell carcinoma: high expression of glucose-transporter 1 (GLUT-1) correlates with low CD8(+) T-cell infiltration in the tumor. Int J Cancer 2011;128:2085-2095.

47 Chevrier S, Levine JH, Zanotelli VRT, Silina K, Schulz D, Bacac M, Ries CH, Ailles L, Jewett MAS, Moch H, van den Broek M, Beisel C, Stadler MB, Gedye C, Reis B, Peser D, Bodenmiller B: An Immune Atlas of Clear Cell Renal Cell Carcinoma. Cell 2017;169:736-749.e18.

48 Bergsten P, Amitai G, Kehrl J, Dhariwal KR, Klein HG, Levine M: Millimolar concentrations of ascorbic acid in purified human mononuclear leukocytes. Depletion and reaccumulation. J Biol Chem 1990;265:2584-2587.

49 Bergsten P, Yu R, Kehrl J, Levine M: Ascorbic acid transport and distribution in human B lymphocytes. Arch Biochem Biophys 1995;317:208-214.

50 Vera JC, Rivas CI, Fischbarg J, Golde DW: Mammalian facilitative hexose transporters mediate the transport of dehydroascorbic acid. Nature 1993;364:79-82.

51 Welch RW, Wang Y, Crossman A Jr, Park JB, Kirk KL, Levine M: Accumulation of vitamin C (ascorbate) and its oxidized metabolite dehydroascorbic acid occurs by separate mechanisms. J Biol Chem 1995;270:1258412592.

52 Dhariwal KR, Hartzell WO, Levine M: Ascorbic acid and dehydroascorbic acid measurements in human plasma and serum. Am J Clin Nutr 1991;54:712-716.

53 Pullar JM, Bayer S, Carr AC: Appropriate handling, processing and analysis of blood samples is essential to avoid oxidation of vitamin C to dehydroascorbic acid. Antioxidants (Basel) 2018;7:29.

54 Padayatty SJ, Sun AY, Chen Q, Espey MG, Drisko J, Levine M: Vitamin C: intravenous use by complementary and alternative medicine practitioners and adverse effects. PLoS One 2010;5:e11414. 
Cellular Physiology Cell Physiol Biochem 2021;55:553-568

\begin{tabular}{ll|l} 
and Biochemistry & $\begin{array}{l}\text { DOl: } 10.33594 / 000000435 \\
\text { Published online: } 2 \text { October } 2021\end{array}$ & $\begin{array}{l}\text { C } 2021 \text { The Author(s). Published by } \\
\text { Cell Physiol Biochem Press GmbH\&Co. KG }\end{array}$ \\
\cline { 2 - 3 }
\end{tabular}

Wohlrab et al.: Vitamin C Transporters in Renal Cell Carcinoma

55 Ngo B, Van Riper JM, Cantley LC, Yun J: Targeting cancer vulnerabilities with high-dose vitamin C. Nat Rev Cancer 2019;19:271-282.

56 Giansanti M, Karimi T, Faraoni I, Graziani G: High-Dose Vitamin C: Preclinical Evidence for Tailoring Treatment in Cancer Patients. Cancers (Basel) 2021;13:1428.

57 Shenoy NK, Ou FS, Cheville JC, Bhagat T, Gartrell BA, Verma A, Levine M, Pagliaro LC: Randomized phase II trial of intravenous ascorbic acid (AA) as an adjunct to pazopanib for metastatic and unresectable clear cell renal cell carcinoma (ccRCC): A study of Academic and Community Cancer Research United (ACCRU) GU1703. J Clin Oncol 2019; DOI: 10.1200/JC0.2019.37.7_suppl.TPS679. 